\section{Quick and easy method for determination of priority phenolic compounds in water and wastewater}

\author{
Bhupander Kumar, Virendra Kumar \\ Verma, Chandra Shekhar Sharma, \\ Avinash B. Akolkar \\ National Reference Trace Organics \\ Laboratory, Central Pollution Control \\ Board, East Arjun Nagar Delhi, India
}

\section{Abstract}

Phenols and phenolic compounds are ubiquitous contaminants in the environment. Due to toxic potential, some phenolic compounds mainly chlorophenols and nitrophenols have been classified as priority pollutants. They enter into the environment through various sources such as industrial, domestic and vehicular emissions. For compliance of national and international regulations, various analytical methods have been developed for assessment in the environmental matrices. This paper presents quick, easy and reliable method for simultaneous determination of eleven priority phenolic compounds in wastewater using reversed-phase high-performance liquid chromatography and diode array detector. Liquid-liquid extraction technique with dichloromethane in acidic condition was used for the extraction, and chromatographic separation of compounds was carried out on a $\mathrm{C} 18$ column with water and methanol as the mobile phase. The following parameters like selectivity/specificity, linearity $\left(R^{2}\right)$, range, limit of detection (LOD) and quantification (LOQ), precision (repeatability) and accuracy (recovery) were validated for consistent and reliable results. Calibration curves for all compounds were linear $\left(R^{2}, 0.998-0.999\right)$ within the concentration range of $5-125(\mu \mathrm{g} / \mathrm{mL})$. The LOD and LOQ of the method ranged between 0.11$0.61 \mu \mathrm{g} / \mathrm{L}$ and $0.37-2.04 \mu \mathrm{g} / \mathrm{L}$, respectively. This method was applied to quantify phenolic compounds in wastewater samples from urban drain with good separated peaks, precision and accuracy.

\section{Introduction}

Phenols and phenolic compounds are aromatic hydroxyl compounds, which are of environmental concern due to their ubiquity in the environment and toxicity at low concentrations. Phenolic compounds may be classified in various groups based on their physicalchemical properties. The most studied groups of phenolic compounds are chlorophenols, nitrophenols, methylphenols, alkylphenols and bisphenols. ${ }^{1}$ These compounds are used or formed mainly in field of chemical, polymers, textile, pharmaceutical, pulp and paper, wood industry, plasticizers, pesticide manufacturing, detergent applications and metallurgic industries. ${ }^{2,3}$

Some phenolic compounds particularly chlorophenols, have been reported as highly toxic, estrogenic, mutagenic and carcinogenic, anti-androgenic and vasodilator. ${ }^{4,5}$ Phenolic toxicity is related to transformation processes by the formation of electrophilic metabolites that may bind and damage DNA or proteins (enzymes). It is also reported that phenol and phenolic compounds inhibit biological activities during wastewaters treatment. ${ }^{6}$

The major anthropogenic sources of phenols to the environment are industrial effluents and domestic sewage. However, phenols may occur naturally in the aquatic environment via degradation of humic substances, tannin and lignin. ${ }^{7}$ Some of phenolic compounds in the environment originate from the production and use of pesticides such as 2,4-dichloro-phenoxyacetic acid (2,4-D), 4-chloro-2-methylphenoxyacetic acid, 2,4,5-trichloro-phenoxyacetic acid (2,4,5-T), 2-methyl-4,6-dinitrophenol (dinoseb), and phenolic biocides like pentachlorophenol. Moreover, nitrophenols and methylphenol enter the environment through vehicle emissions. ${ }^{4}$

As a result, relatively large amount of phenolic compounds has the potential to reach aquatic environments and frequently found in aquatic environments. ${ }^{2,8-14}$ In recent years, increasing attention has been paid to phenolic compounds, due to increasing concerns about their toxicity potential and negative impacts on the environment. ${ }^{11,15-18}$ Therefore, some phenols mainly chlorophenols and nitrophenols, have been classified as priority pollutants by world health organization (WHO) ${ }^{19}$ United States environmental protection agency

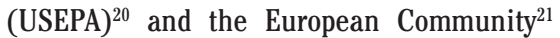
(Table 1).

Reliable analytical methods are required for compliance with national and international regulations. ${ }^{22}$ Several analytical methods have been frequently used for determination of phenol or their derivatives in the environmental matrices. Liquid-liquid extraction (LLE) and solid-phase extraction are the most commonly used techniques for pre-concentration phenols. ${ }^{23,24}$ For quantitative detection, most frequently used chromatographic methods are gas chromatography (GC) combined with flame ionization detection or gas chromatography mass spectrometry (GC-MS) detection. ${ }^{1,7,13,14,16,25,26}$ However, in GC analysis derivatization step is needed for nonvolatile
Correspondence: Bhupander Kumar, National Reference Trace Organics Laboratory, Central Pollution Control Board, East Arjun Nagar, Delhi110032 , India.

Tel.: +91.01143102378.

E-mail: bhupander_kumar@yahoo.com

Key words: Priority phenolic compounds, highperformance liquid chromatography, method development, wastewater.

Acknowledgments: the authors are thankful to the Chairman and Member Secretary, Central Pollution Control Board for the permission and guidance to conduct this work.

Received for publication: 27 August 2014 Revision received: 21 November 2014. Accepted for publication: 21 November 2014.

This work is licensed under a Creative Commons Attribution NonCommercial 3.0 License (CC BYNC 3.0).

CC Copyright B. Kumar et al., 2014

Licensee PAGEPress, Italy

Journal of Xenobiotics 2014; 4:4680

doi:10.4081/xeno.2014.4680

compounds which results most of the time GC columns degradation. ${ }^{27}$ Moreover, derivatization increases the sample preparation time and represent another source of errors. Therefore, alternative methods of high performance liquid chromatography (HPLC) methods combined with UV/diode array detector (DAD), ${ }^{28,29}$ electrochemical, ${ }^{30,31}$ and fluorescence $^{32}$ detections are more suitable for analysis of priority phenolic compounds.

The aim of this work was to develop and validate a simple and reliable method for extraction, identification and quantification of eleven priority phenolic compounds in wastewater. For this purpose, extraction of wastewater samples was done with dichloromethane in acidified condition and quantification of eleven phenolic compounds was carried out with HPLC coupled with DAD using methanol/water as mobile phase.

\section{Materials and Methods}

\section{Chemicals, solvents and standards}

Solvents (dichloromethane and methanol), chemicals (sodium sulphate, sulfuric acid, and ortho-phosphoric acid) and water procured from Rankem, India. All solvents and water was HPLC grade and chemicals were analytical grade. Individual eleven priority phenols namely (phenol, 2-chlorophenol, 2,4dichlorophenol, 2,4,6-trichlorophenol, pentachlorophenol, 2-nitrophenol, 4-nitrophenol, 2,4-dinitrophenol, 2-methyl-4,6-dinitrophenol, 
Table 1. Physical properties of priority phenolic compounds. ${ }^{15}$

\begin{tabular}{|c|c|c|c|c|c|c|c|c|}
\hline Compounds & CAS No. & $\begin{array}{l}\text { Molar mass } \\
(\mathrm{g} / \mathrm{mol})\end{array}$ & $\begin{array}{l}\text { Melting point } \\
\left({ }^{\circ} \mathrm{C}\right)\end{array}$ & $\begin{array}{l}\text { Boiling point } \\
\left({ }^{\circ} \mathrm{C}\right)\end{array}$ & $\begin{array}{l}\text { Density } \\
\left(\mathrm{g} / \mathrm{cm}^{3}\right)\end{array}$ & pKa & $\begin{array}{c}\text { Log Kow } \\
\text { (octanol/water) }\end{array}$ & $\begin{array}{c}\text { Water } \\
\text { solubility } \\
\left(\mathrm{g} / \mathrm{L} \text { at } 20^{\circ} \mathrm{C}\right)\end{array}$ \\
\hline Phenol & $108-95-2$ & 94.11 & 40.8 & 181.8 & $1.06\left(20^{\circ} \mathrm{C}\right)$ & 10.0 & 1.46 & 83 \\
\hline 4-nitrophenol & $93951-79-2$ & 139.11 & $110-115$ & 279 & $1.48\left(20^{\circ} \mathrm{C}\right)$ & 7.08 & 2.04 & 11.6 \\
\hline 2,4-dinitrophenol & $51-28-5$ & 184.11 & $114-115$ & 113 & $1.68\left(20^{\circ} \mathrm{C}\right)$ & 3.94 & 1.67 & 5.45 \\
\hline 2-nitrophenol & $88-75-5$ & 139.11 & $43-45$ & 215-216 & $1.26\left(20^{\circ} \mathrm{C}\right)$ & 7.23 & 1.89 & 2.50 \\
\hline 2-chlorophenol & $95-57-8$ & 128.55 & 7 & 174 & $1.26\left(20^{\circ} \mathrm{C}\right)$ & 8.56 & 2.15 & 28.5 \\
\hline 2,4-dimethylphenol & $105-67-9$ & 122.16 & 25 & 211 & $1.016\left(20^{\circ} \mathrm{C}\right)$ & - & - & - \\
\hline 2-methyl-4,6-dinitrophenol & $534-52-1$ & 198.14 & $82-85$ & 312 & - & 10.58 & 2.30 & 0.05 \\
\hline 4-chloro-3-methylphenol & $59-50-7$ & 142.58 & $63-65$ & $235-239$ & $1.37\left(20^{\circ} \mathrm{C}\right)$ & 9.6 & 3.10 & 4 \\
\hline 2,4-dichlorophenol & $120-83-2$ & 163 & $40-43$ & 209-211 & - & 7.85 & 3.06 & 4.5 \\
\hline 2,4,6-trichlorophenol & $88-06-2$ & 197.44 & $65-68$ & $244-246$ & $1.675\left(20^{\circ} \mathrm{C}\right)$ & 69 & 6.15 & 3.69 \\
\hline Pentachlorophenol & $87-86-5$ & 266.34 & 190-191 & 309-310 & $1.978\left(20^{\circ} \mathrm{C}\right)$ & 4.7 & 5.12 & 0.01 \\
\hline
\end{tabular}

2,4-dimethylphenol, 4-chloro-3-methylphenol) and EPA phenol mixture standard solutions were procured from Supelco (Bellefonte, PA, USA). Ultra pure water was prepared using a Mili-Q plus water purifications system.

\section{Instrumentation}

Glassware involved in the method was cleaned with detergent followed by deionised water and finally solvents rinse and dried in hot air oven. Manual LLE technique using separating funnel (1L) was followed for phenolic compound extraction from water. Vacuum rotary evaporator (Eyela, Tokyo, Japan), Turbovap (Caliper, USA) and Minivap (Supelco, USA) were used for extract concentrations. HPLC system (Series 1100, Agilent Technology Inc., Santa Clara, CA, USA) was used in combination with a quaternary solvent delivery system with vacuum degasser unit, auto sampler, column oven, and UV-DAD (ultra violet-diode array detector) $(\lambda=280 \mathrm{~nm})$ for the chromatographic analysis.

\section{Synthetic sample}

The synthetic water was used in order to avoid interference in the chromatographic separation and in the detection response. Synthetic sample was prepared in the laboratory with the addition of known quantities of eleven phenolic compounds in Milli- $Q$ water. Synthetic water sample was adjusted to $\mathrm{pH}<2$ with $50 \%$ sulfuric acid in water (1:1v/v), preserved in brown glass bottle with teflon lined screw cap, and processed by extraction within same day.

\section{Sample extraction}

Liquid-liquid extraction in separatory funnel was carried out three times with $50 \mathrm{~mL}$ of dichloromethane for 2 min each. The organic phase was passed through anhydrous sodium sulphate to remove traces of water contents and the extracts were concentrated to near 5

Table 2. High performance liquid chromatography conditions for the determination of phenolic compounds.

\begin{tabular}{ll}
$\begin{array}{ll}\text { Conditions } \\
\text { Injection volume }\end{array}$ & $10 \mu \mathrm{L}$ \\
Guard column & $\mathrm{C} 18(4.6 \times 12.5 \mathrm{~mm}, 5 \mu \mathrm{m}$ diameter particle size $)$ \\
\hline Analytical column & $\begin{array}{l}\mathrm{C} 18(4.6 \times 250 \mathrm{~mm}, 5 \mu \mathrm{m} \text { diameter particle size }) \\
\text { (Ascentis }{ }^{\circledR}, \text { Supelco, Bellefonte, PA, USA) }\end{array}$ \\
Mobile phase composition & $\mathrm{A}(0.1 \%$ o-phosphoric acid in HPLC Water $)$ \\
& $\mathrm{B}(0.1 \%$ o-phosphoric acid in Methanol $)$ \\
\hline Gradient & 20 to $95 \%$ B in 30 min \\
Mobile phase flow rate & $0.7 \mathrm{~mL} / \mathrm{min}$ \\
\hline Column temperature & $25 \pm 1^{\circ} \mathrm{C}$ \\
Detection & Diode array detector (DAD), $280 \mathrm{~nm}$
\end{tabular}

mL by vacuum rotary evaporator (Eyela, Tokyo, Japan). Extract solvent was exchanged with methanol by the addition of $50 \mathrm{~mL}$ methanol, and again concentrated again to near $5 \mathrm{~mL}$. Special care was taken to remove traces of dichloromethane to avoid interferences during chromatographic analysis. The concentrated extract volume was reduced to $1.0 \mathrm{ml}$ under gentle stream of purified nitrogen gas using Turbo Vap (Caliper, USA) and Minivap (Supelco, USA).

\section{High-performance liquid chromatography conditions} for phenolics analysis

The chromatographic identification and quantification was performed using Agilent (Series 1100, Agilent Technology Inc., Santa Clara, CA, USA) high performance liquid chromatograph (HPLC), equipped with a vacuum degasser (Agilent, G1379A), quaternary pump (Agilent, G1311A), diode array detector (Agilent, G1315B) and an autosampler (Agilent, G1329B). Chromatographic conditions for the determination of phenolic compounds are presented in Table 2. A $10 \mu \mathrm{L}$ vol- ume of methanol extract was separated on a C18 reversed-phase analytical column $(4.6 \times 250 \mathrm{~mm}, 5 \mu \mathrm{m}$ diameter particle $)$ (Ascentis $^{\circledR}$, Supelco, USA). Before analytical column, a guard column $(4.6 \times 12.5 \mathrm{~mm}, 5 \mu \mathrm{m}$ diameter particle) used to prevent any contamination into the column. Gradient flow was set at $0.7 \mathrm{~mL} / \mathrm{min}$ of $0.1 \%$-phosphoric acid in methanol and $0.1 \%$ o-phosphoric acid in water was used for elution during analysis. The mobile phase conditions varied from $20 \%$ methanol to $95 \%$ in 30 min and then come back to the initial conditions at $60 \mathrm{~min}$. Peaks were determined at $280 \mathrm{~nm}$ for all phenolic compounds. The controlled ambient temperature in column was $25 \pm 1^{\circ} \mathrm{C}$. The Agilent Chemstation software (Rev. B.02.01) was used to control the chromatographic conditions and data acquisition.

\section{Basic analytical quality control}

The method was performed with general quality assurance (replicate sample, instrument calibration verification and repeatability check of the instrument). Method blanks in triplicate were processed as real samples to 
check any cross contaminations or loss of the analytes. Calibration standard solutions were prepared at the time of instrument calibration with every batch of analysis. The calibration curves followed the Beer's law in the investigation range of phenolic compounds injected in the column. Calibration of the instrument was carried out by injecting amount of the five level phenolic compounds (5-125 $\mu \mathrm{L})$ as a function of peak area using linear fit. Data obtained for instrument calibration, i.e. regression equation, standard deviation (SD) and the value of the multiple correlation coefficients $\left(R^{2}\right)$ of the instruments are presented in Table 3 . Measurements were repeated three times for each sample and the results were averaged and expressed relative to the average result for the method blank (concentration, $<\mathrm{DL} B D L$ ). The limit of detection (LOD) and quantification (LOQ) were estimated at signal to noise ratio $>3: 1$ and 10:1, respectively. The method performance and matrix effects were checked by analyzing real samples spiked with standard.

\section{Method validation parameters}

Before adopting an analytical method for consistent, reliable and accurate data, validation of method is necessary. Various parameters have been defined the validation of analytical methods. ${ }^{22,33-37}$ During our study, we validated the following briefly described parameters:

Specificity: The ability of an analytical method is to differentiate and quantify the analytes in the presence of other compound in the sample. Specificity in chromatographic analysis was obtained by optimizing chromatographic conditions. In addition to chromatographic separation, the sample preparation step was also optimized for optimal selectivity. $22,33,34,37$ Optimized specific HPLC conditions were followed for selectivity by analyses of blank samples (extracted distilled water) in triplicates. Each blank sample tested for interference, and selectivity was lower than LOD. The specificity of the method was determined by analyzing the standard solution containing all the eleven phenolic compounds. For this purpose $10 \mu \mathrm{L}$ of one of the standard solutions was injected into the HPLC system and the specificity of the method was measured in terms of the resolution between the two peaks (retention times) without overlapping of the peaks (Table 3).

Linearity and range: After dilution of the stock standard solution, an intermediate mixed standard solution was prepared. Intermediate and working standard solutions were prepared in methanol and stored at $4^{\circ} \mathrm{C}$ in the dark. Five levels of calibration working solutions for each compound were prepared and chromatographed by injecting $10 \mu \mathrm{L}$. A calibration curve for eleven phenolic compounds was prepared separately by plotting peak area (y-axis) versus concentration (x-axis). All curves were constructed using the external standard method. The peak identification of the analytes was done by the accurate retention time of each individual standard. Calibration was verified by analyzing the middle level calibration standard and the relative percent difference between expected concentration and obtained responses from the fivepoint calibrations. The calibration curve was fitted by linear least-squares regression and the value obtained for the correlation coefficient indicated that the method is linear in the range of concentrations studied (Table 3 ).

Limits of detection and quantification: LODs and LOQs were determined as the lowest phenolic concentration injected that yielded a signal-to-noise $(\mathrm{S} / \mathrm{N})$ ratio of 3 and 10 , respectively. The LOD and LOQ were obtained by processing the eight aliquots of a spiked sample with smallest quantity of the standard materials to produce a valid quantifiable peak for a $10 \mu \mathrm{L}$ of injection. The detection limit was calculated as per the standard guidelines ${ }^{22,33-39}$ with the following equations:

Limit of detection (LOD) $=$ SD $\times 3$

Limit of quantification $\mathrm{LOQ}=\mathrm{SD} \times 10$

where, SD is the standard deviation of response of 7 replicate analysis. The estimated detection limits for all eleven phenolic compounds were presented in Table 3 .

Accuracy or Recovery: Accuracy of an analytical method is the closeness of agreement between the conventional true value or an accepted reference value and the value observed. Trueness or bias in terms of accuracy/recovery was determined through the percent recovery with addition of the standard solution to the distilled water and wastewater sample in triplicates at different levels concentrations of phenolic compounds. The average percent recovery was calculated using the following equation:

Recovery (\%) = (observed $_{\text {Concentration }} /$ spiked $\left._{\text {Concentration }}\right)$ x 100

where observed $\mathrm{d}_{\text {Concentration }}$ is the concentration observed in the samples and spiked Concentration $_{\text {is }}$ the initial concentration spiked to the sample. Obtained method recoveries for individual phenolic compounds spiked in distilled water and wastewater presented in Tables 4 and 5 , respectively.

Precision: Precision is the closeness of agreement between independent test results obtained under validated conditions. The precision of this method was based on the retention time and the average concentration in standard solution and wastewater sample. The precision was evaluated through the interme-

Table 3. Calibration data for linearity, retention times, regression, calibration verification and detection limits.

\begin{tabular}{lccccccc} 
Compounds & $\begin{array}{c}\text { Range } \\
(\mu g / L)\end{array}$ & $\begin{array}{c}\text { RT } \\
(\mathrm{min})\end{array}$ & $\begin{array}{c}\text { Regression } \\
\text { equation* }\end{array}$ & $R^{2}$ & $\begin{array}{c}\text { Calibration (\%) } \\
\text { verification }\end{array}$ & $\begin{array}{c}\text { LOD } \\
(\mu g / L)\end{array}$ & $\begin{array}{c}\text { LOQ } \\
(\mu g / L)\end{array}$ \\
Phenol & $5-25$ & 18.60 & $\mathrm{y}=8.345 \mathrm{x}-2.893$ & 0.998 & 0.008 & 0.18 & 0.61 \\
4-nitrophenol & $25-125$ & 21.85 & $\mathrm{y}=1.876 \mathrm{x}-1.003$ & 0.999 & 0.006 & 0.61 & 2.04 \\
\hline 2,4-dinitrophenol & $15-75$ & 23.45 & $\mathrm{y}=28.69 \mathrm{x}-15.53$ & 0.998 & 0.003 & 0.33 & 1.09 \\
2-nitrophenol & $5-25$ & 24.14 & $\mathrm{y}=21.27 \mathrm{x}-6.999$ & 0.998 & 0.003 & 0.11 & 0.37 \\
\hline 2-chlorophenol & $5-25$ & 24.47 & $\mathrm{y}=12.38 \mathrm{x}-6.131$ & 0.998 & 0.008 & 0.11 & 0.38 \\
2,4-dimethylphenol & $5-25$ & 27.52 & $\mathrm{y}=12.82 \mathrm{x}-4.070$ & 0.998 & 0.007 & 0.11 & 0.38 \\
\hline 2-methyl-4,6-dinitrophenol & $25-125$ & 28.60 & $\mathrm{y}=36.02 \mathrm{x}-18.88$ & 0.998 & 0.007 & 0.54 & 1.81 \\
4-chloro-3-methylphenol & $25-125$ & 29.19 & $\mathrm{y}=9.190 \mathrm{x}-3.776$ & 0.998 & 0.005 & 0.57 & 1.89 \\
\hline 2,4-dichlorophenol & $5-25$ & 30.46 & $\mathrm{y}=8.804 \mathrm{x}-2.981$ & 0.998 & 0.013 & 0.32 & 1.08 \\
2,4,6-trichlorophenol & $15-75$ & 33.64 & $\mathrm{y}=5.845 \mathrm{x}-1.803$ & 0.999 & 0.004 & 0.38 & 1.28 \\
\hline Pentachlorophenol & $25-125$ & 38.63 & $\mathrm{y}=2.142 \mathrm{x}-1.417$ & 0.998 & 0.015 & 0.60 & 1.98
\end{tabular}

RT, retention time; LOD, limit of detection; LOQ, limit of quantification. ${ }^{*} \mathrm{Y}=\mathrm{ax}+\mathrm{b}$ (where, $\mathrm{y}$ : instrument response as peak area, a: slope of calibration curve, $\mathrm{x}$ : concentration of calibration standard, b: intercept of the calibration curve). 
diate precision method and within-day repeatability, for which 7 injections of the standard solution and wastewater sample were carried out. Precision as repeatability was expressed as SD and relative standard deviation (RSD) in Table 6.

\section{Calculation of results}

The results were to be calculated as follows:

Phenolic compound concentration $(\mu \mathrm{g} / \mathrm{L})=$ $(\mathrm{AxB} / \mathrm{C})$

where:

$\mathrm{A}^{*}=$ Concentration of analyte obtained from instrument $(\mu \mathrm{g})$

$\mathrm{B}=$ Final extract volume $(\mathrm{mL})$

$\mathrm{C}=$ Initial sample volume taken (L)

*Based upon the average of 3 separate determinations of each solution. Blank value must be deducted.

\section{Application of method}

To assess application of this method, determination of priority eleven phenolic compounds was carried out in wastewater samples. 1L water sample in triplicate in amber bottles was collected from municipal drain in Delhi. Ice preserved samples transported to laboratory, filtered and stored at $4^{\circ} \mathrm{C}$ in dark. A known quantities of phenolic compounds were spiked and left overnight to equilibrate. Spiked wastewater samples were adjusted to $\mathrm{pH}<2$ with $50 \%$ sulfuric acid in water (1:1v/v), extracted and analyzed with this method. The average concentrations and of individual phenolic compounds were presented in Table 6 .

\section{Results}

Before extraction, samples were acidified to $\mathrm{pH}<2$ with the addition of 1:1 (v/v) sulfuric acid. Generally, $1.0 \mathrm{~mL}$ of sulfuric acid was sufficient to reduced $\mathrm{pH}<2$ for normal water samples and wastewater samples. For extraction different volume of dichloromethane was tested, but extraction with $50 \mathrm{ml}$ dichloromethane three times produced sufficient extraction efficiency (Tables 4 and 5).

The peak shape, retention time and chromatographic spectrum did not show any possible interference. No interfering or overlapping peaks were observed in the chromatograms at the specific retention time for each compound and in all cases, compared with the standard solution.

Five point calibration curves were verified with known standard solution and found to be within range of $0.003-0.015 \%$. Calibration curves were linear over the test concentration range. The minimum specified range is 80 to 120 percent of the expected test concentration
Table 4. Determination of the method accuracy as recovery (\%) of phenolic compounds from distilled water spiked with different levels of standard concentration $(n=3)$.

\begin{tabular}{|c|c|c|c|c|c|}
\hline \multirow[t]{2}{*}{ Compounds } & \multirow{2}{*}{$\begin{array}{c}\text { Spiked } \\
\text { level ( } \mu / \mathrm{L} / \mathrm{L})\end{array}$} & \multicolumn{2}{|c|}{ Range (\%) } & \multirow{2}{*}{$\begin{array}{l}\text { Mean } \\
(\%)\end{array}$} & \multirow{2}{*}{$\begin{array}{l}\text { SD } \\
(\%)\end{array}$} \\
\hline & & Min & Max & & \\
\hline \multirow[t]{2}{*}{ Phenol } & 10 & 42 & 44 & 43 & 0.99 \\
\hline & 25 & 38 & 42 & 39 & 2.3 \\
\hline \multirow[t]{2}{*}{ 4-nitrophenol } & 50 & 60 & 62 & 61 & 0.94 \\
\hline & 125 & 46 & 49 & 47 & 1.6 \\
\hline \multirow[t]{2}{*}{ 2,4-dinitrophenol } & 30 & 100 & 102 & 102 & 1.6 \\
\hline & 75 & 97 & 115 & 104 & 9.4 \\
\hline \multirow[t]{2}{*}{ 2-nitrophenol } & 10 & 42 & 71 & 61 & 17 \\
\hline & 25 & 84 & 93 & 88 & 4.6 \\
\hline \multirow[t]{2}{*}{ 2-chlorophenol } & 10 & 87 & 110 & 95 & 12 \\
\hline & 25 & 91 & 101 & 94 & 5.9 \\
\hline \multirow[t]{2}{*}{ 2,4-dimethylphenol } & 10 & 89 & 91 & 91 & 1.1 \\
\hline & 25 & 98 & 107 & 103 & 4.6 \\
\hline \multirow[t]{2}{*}{ 2-methyl-4,6-dinitrophenol } & 50 & 98 & 101 & 100 & 1.8 \\
\hline & 125 & 91 & 110 & 99 & 9.6 \\
\hline \multirow[t]{2}{*}{ 4-chloro-3-methylphenol } & 50 & 95 & 99 & 98 & 2.1 \\
\hline & 125 & 101 & 111 & 104 & 5.8 \\
\hline \multirow[t]{2}{*}{ 2,4-dichlorophenol } & 10 & 84 & 89 & 87 & 3.2 \\
\hline & 25 & 94 & 103 & 97 & 4.8 \\
\hline \multirow[t]{2}{*}{ 2,4,6-trichlorophenol } & 30 & 93 & 96 & 95 & 1.6 \\
\hline & 75 & 94 & 110 & 101 & 7.8 \\
\hline \multirow[t]{2}{*}{ Pentachlorophenol } & 50 & 97 & 112 & 104 & 7.5 \\
\hline & 125 & 92 & 112 & 105 & 11 \\
\hline
\end{tabular}

SD, standard deviation.

Table 5. Determination of the method accuracy as recovery (\%) of phenolic compounds from wastewater spiked with different levels of standard concentration $(n=3)$.

\begin{tabular}{lccccc} 
Compounds & $\begin{array}{c}\text { Spiked } \\
\text { level (1/g/L) }\end{array}$ & \multicolumn{2}{c}{ Range (\%) } & Mean & SD \\
Phenol & 15 & 35 & 37 & 36 & $(\%)$ \\
& 25 & 29 & 31 & 30 & 1.2 \\
4-nitrophenol & 75 & 49 & 59 & 53 & 1.2 \\
& 125 & 53 & 55 & 54 & 0.9 \\
\hline 2,4-dinitrophenol & 45 & 81 & 106 & 91 & 11 \\
& 75 & 87 & 110 & 101 & 13 \\
2-nitrophenol & 15 & 20 & 24 & 22 & 1.5 \\
& 25 & 43 & 56 & 51 & 6.8 \\
\hline 2-chlorophenol & 15 & 100 & 118 & 106 & 9.5 \\
& 25 & 57 & 63 & 61 & 3.6 \\
2,4-dimethylphenol & 15 & 71 & 88 & 78 & 7.2 \\
& 25 & 68 & 73 & 71 & 2.1 \\
\hline 2-methyl-4,6-dinitrophenol & 75 & 81 & 105 & 91 & 11 \\
& 125 & 91 & 110 & 103 & 10.2 \\
4-chloro-3-methylphenol & 75 & 76 & 97 & 85 & 9.3 \\
& 125 & 79 & 91 & 85 & 6.0 \\
\hline 2,4-dichlorophenol & 15 & 77 & 114 & 90 & 17 \\
& 25 & 69 & 72 & 71 & 1.4 \\
2,4,6-trichlorophenol & 45 & 76 & 99 & 85 & 10 \\
& 75 & 71 & 80 & 75 & 4.6 \\
\hline Pentachlorophenol & 75 & 82 & 109 & 95 & 11 \\
& 125 & 106 & 110 & 109 & 2.5 \\
\hline
\end{tabular}

SD, standard deviation. 
Table 6. Precision as repeatability of the method based on the retention time and concentration in standard solution and wastewater.

\begin{tabular}{|c|c|c|c|c|c|c|c|c|c|}
\hline \multirow[t]{2}{*}{ Compounds } & \multicolumn{3}{|c|}{ Retention time ( $n=7)$} & \multicolumn{3}{|c|}{ Standard solution $(\mathrm{n}=7)$} & \multicolumn{3}{|c|}{ Waste water sample $(n=7)$} \\
\hline & Min & $\begin{array}{l}\text { SD } \\
( \pm)\end{array}$ & RSD & $\begin{array}{l}\text { Conc. } \\
\text { ( } \mu / \mathrm{g} / \mathrm{L})\end{array}$ & $\begin{array}{l}\text { SD } \\
( \pm)\end{array}$ & $\begin{array}{l}\text { RSD } \\
(\%)\end{array}$ & $\begin{array}{l}\text { Conc. } \\
\text { ( } \mu \mathrm{g} / \mathrm{L})\end{array}$ & $\begin{array}{l}\text { SD } \\
( \pm)\end{array}$ & $\begin{array}{l}\text { RSD } \\
(\%)\end{array}$ \\
\hline Phenol & 18.60 & 0.08 & 0.43 & 9.05 & 0.08 & 0.84 & 5.20 & 0.02 & 0.48 \\
\hline 4-nitrophenol & 21.85 & 0.30 & 1.38 & 8.95 & 0.05 & 0.60 & 36.54 & 0.02 & 0.05 \\
\hline 2,4-dinitrophenol & 23.45 & 0.30 & 1.32 & 8.96 & 0.03 & 0.29 & 36.42 & 0.07 & 0.18 \\
\hline 2-nitrophenol & 24.14 & 0.07 & 0.29 & 9.03 & 0.02 & 0.26 & 3.09 & 0.02 & 0.52 \\
\hline 2-chlorophenol & 24.47 & 0.04 & 0.16 & 9.07 & 0.07 & 0.75 & 14.41 & 0.05 & 0.37 \\
\hline 2,4-dimethylphenol & 27.52 & 0.16 & 0.58 & 9.13 & 0.06 & 0.68 & 10.69 & 0.00 & 0.03 \\
\hline 2-methyl-4,6-dinitrophenol & 28.60 & 0.30 & 1.08 & 9.05 & 0.07 & 0.72 & 60.71 & 0.13 & 0.22 \\
\hline 4-chloro-3-methylphenol & 29.19 & 0.24 & 0.85 & 9.11 & 0.04 & 0.48 & 57.32 & 0.13 & 0.23 \\
\hline 2,4-dichlorophenol & 30.46 & 0.51 & 1.70 & 9.27 & 0.12 & 1.27 & 11.53 & 0.07 & 0.60 \\
\hline 2,4,6-trichlorophenol & 33.64 & 0.28 & 0.83 & 9.20 & 0.04 & 0.40 & 34.08 & 0.08 & 0.23 \\
\hline Pentachlorophenol & 38.63 & 0.39 & 1.01 & 9.18 & 0.13 & 1.47 & 62.42 & 1.18 & 1.88 \\
\hline
\end{tabular}

SD, standard deviation; RSD, relative standard deviation; Conc., concentration.

ranges. ${ }^{33-34,40}$ The results of the regression analysis and linearity of calibration range are shown in Table 3 . The observed linearity $\left(R^{2}\right)$ ranged between $0.998-0.999$ for all the eleven phenolic compounds.

The estimated LOD and LOQ are presented in Table 3. LOD ranged between $0.11-0.61 \mu \mathrm{g} / \mathrm{L}$ while $\mathrm{LOQ}$ varies between $0.37-2.04 \mu \mathrm{g} / \mathrm{L}$.

Due to non-availability of certified reference material, recovery study was undertaken by the addition of known quantity of phenolic compound standards at different levels of concentration in distilled water (Table 4) and wastewater (Table 5). The added standard concentrations were within calibration range. The average recovery of phenol, nitrophenols and chlorophenols ranged between $39-43 \%$, 47$104 \%$ and $87-105 \%$, respectively in distilled water. However, in wastewater, recoveries for phenol, nitrophenols and chlorophenols were between $30-36 \%, 53-91 \%$ and $61-109 \%$, respectively.

The precision of this methodology was based on the retention time and average concentration of phenolic compounds in standard solution and known standard spiked wastewater samples (Table 6). The SD values obtained in this study, ranged 0.04-0.51, 0.020.13 and $0.02-1.18$, respectively for retention time, average concentration in standard solution and wastewater. However, their RSD ranged $0.16-1.70 \%, 0.26-1.47 \%$ and $0.03-1.88 \%$ for retention time, average concentration of phenolic compounds in standard solution and wastewater sample, respectively.

\section{Discussion}

The objective of our work was to develop a simple procedure suitable for extraction and determination of priority phenolic compounds in wastewater. Calibration curves were linear over the test concentration range and within the minimum specified range of $80-120$ percent. $^{33-34,40}$ The observed linearity was within acceptable range ${ }^{38}$ indicating an excellent fit of the phenolic compounds within the range studied. A linear regression equation applied to the results should have an intercept not significantly different from zero. A significant nonzero intercept was obtained, which demonstrated that this linearity has no effect on the accuracy of the method.

The observed values of LOD were three times lower than LOQ shows that method is sensitive for determination of phenolic compounds in water samples. These values are better than those obtained by other workers, which uses different method of extraction and detection. ${ }^{23,41}$

Accuracy of an analytical method is the closeness of agreement between the true value or reference value and the value observed for the specified compound in test material. Trueness or bias was determined by comparing the response of the method to a reference test material with the known value assigned to the material. At the studied levels of fortification, observed recoveries were comparatively low for phenol (range, 29-62\%) and for some nitrophenols (range, 42-115\%). These recoveries were similar with other studies. ${ }^{16,41}$ However, the observed recoveries for other phenolic compounds were in agreement with other studies. ${ }^{14,25,28,29,40}$ The standard deviations of all the recovery experiments were lower than $17 \%$. Variation in recoveries may be better explained with their physical-chemical properties (Table 1). In general, these compounds dissolve weakly in water, but well in organic solvents. Their water solubility decreases with increasing number of chlorine atoms in a molecule. Moreover, fate of these compounds in water depend on the dissociation constant $(K a)$ and the partition coefficient $\left(K_{0 W}\right)$. The dissociation constant and partition coefficient increases with the number of chlorine atoms and the water solubility (hydrophilicity) inversely decreases. Therefore, obtained recovery results (Tables 4 and 5) may be well correlated with the physic-chemical properties of the studied phenolic compounds (Table 1). ${ }^{25}$ Precision results obtained under validated conditions were within acceptable limit of central value. ${ }^{33-35}$

\section{Conclusions}

This method is easy, sensitive and reliable for the determination of eleven priority phenolic compounds in less than 40 min with acceptable analytical precision, accuracy, sensitivity and selectivity. The limit of detection ranged between 0.11-0.61 $\mu \mathrm{g} / \mathrm{L}$ for all the eleven phenolic compounds extracted with LLE and detected by DAD. The calibration was linear with correlation coefficient $>0.99$ for all the eleven compounds. Precision was within acceptable limit of central value. The developed method was successfully applied to the quantitative analysis of eleven phenolic compounds in the wastewater from urban drain.

\section{References}

1. Padilla-Sanchez JA, Plaza-Bolanos P, Romero-Gonzalez R, Garrido-Frenich A, Vidal JLM. Application of a quick, easy, 
cheap, effective, rugged and safe-based method for the simultaneous extraction of chlorophenols, alkylphenols, nitrophenols and cresols in agricultural soils, analyzed by using gas chromatography-triple quadrupole-mass spectrometry/mass spectrometry. J Chromatogr A 2010;1217:572431.

2. Grynkiewicz M, Polkowska Z, Kot-Wasik A, Namiesnik J. Determination of phenols in runoff. Polish J Environ Stud 2002;11:85-89.

3. Santana CM, Ferrera ZS, Padron MET, Rodrigues JJS. Methodologies for the extraction of phenolic compounds from environmental samples: new approaches. Molecules 2009;14:298-320.

4. Michalowicz J, Duda W. Phenols-Sources and toxicity. Polish J Environ Stud 2007;16:347-62.

5. Olujimi 00, Fatoki OS, Odendaal JP, Okonkwo J0. Endocrine disrupting chemicals (phenol and phthalates) in the South African environment: a need for more monitoring. Water SA 2010;36:671-82.

6. Guedes SF, Leitao AL. Effect of phenolic compounds on osmotic stress on the expression of penicillin biosynthetic genes from penicillium chrysogenum var. halophenolicum strain. J Xenobiotics 2012;2:7-12.

7. Sim W, Lee S, Lee I, Choi S, Oh J. Distribution and formation of chlorophenols and bromophenols in marine and riverine environments. Chemosphere 2009;77:552-8.

8. Bolz U, Hagenmaier H, Korner W. Phenolic xenoestrogens in surface water, sediments, and sewage sludge from BadenWurttemberg, south-west Germany. Environ Poll 2001;115:291-301.

9. Zhang B, Zhang MH, Liu PY, Bao ZC, Xu $\mathrm{XB}$. Distribution of pentachlorophenol in Dongting Lake environmental medium. China Environ Sci 2001;21:165-7.

10. Qu LJ, Xian QM, Zou HX. Determination of chlorophenols in drinking water and water resource by solid phase microextraction and gas chromatography. Environ Poll Control 2004;26:154-7.

11. Chen HR, Zhu LZ, Yang K, Ge F, Chen YY. Concentration and pollution characteristics of phenolic compounds in Qiantang River. China Environ Sci 2005;25:729-32.

12. Gao JJ, Liu LH, Liu XR, Zhou HD, Huang $\mathrm{SB}$, Wang ZJ. Levels and spatial distribution of chlorophenols 2,4-dichlorophenol, 2,4,6-trichlorophenol, and pentachlorophenol in surface water of China. Chemosphere 2008;71:1181-7.

13. Zhong WJ, Wang DH, Xu XW, Luo QA, Wang BY, Shan XQ, et al. Screening level ecological risk assessment for phenols in surface water of the Taihu Lake. Chemosphere 2010;80:998-1005.
14. Zhong WJ, Wang DH, Xu XW, Wang BY, Luo $\mathrm{Q}$, Senthilkumaran $\mathrm{S}$, et al. A gas chromatography/mass spectrometry method for the simultaneous analysis of 50 phenols in wastewater using deconvolution technology. Chinese Sci Bull 2011;56:275-84.

15. Davi ML, Gnudi F. Phenolic compounds in surface water. Water Res 1999;33:3213-9.

16. Vidal JLM, Vega AB, Frenich AG, Gonzalez FJE, Liebanas FJA. Determination of fifteen priority phenolic compounds in environmental samples from Andalusia (Spain) by liquid chromatography-mass spectrometry. Anal Bioanal Chem 2004;379:125-30.

17. Koistinen J, Jussi VK, Sormunen A, Mannila E, Herve S, Vartiainen $T$. Bioaccumulation, bioavailability and environmental fate of chlorophenol impurities, polychlorinated hydroxydiphenylethers and their methoxy analogues. Chemosphere 2007;68:1382-91.

18. Xing L, Liu H, Giesy JP, Zhang X, Hongxia Yu H. Probabilistic ecological risk assessment for three chlorophenols in surface waters of China. J Environ Sci 2012;24: 329-34.

19. WHO. Environmental health criteria 93. Chlorophenols other than pentachlorophenol. Geneva: World Health Organization; 1989.

20. USEPA (United States Environmental Protection Agency). Appendix A to 40 CFR, Part 423--126 Priority Pollutants. Available from: http://water.epa.gov/scitech/methods/cwa/pollutants.cfm. Accessed: 20.02 . 2014.

21. EC (European Community). The list of priority substances in the field of water policy and amending directive, Council directive 2455/2001/ECC. Official Journal 2001, L $331, \mathrm{pp} 1-5$.

22. Thompson M, Ellison SLR, Wood E. Harmonized guidelines for single laboratory validation of methods of analysis (IUPAC Technical Report). Pure Appl Chem 2002;74:835-55.

23. Zhao L, Lee HK. Determination of phenols in water using liquid phase microextraction with back extraction combined with high-performance liquid chromatography. J Chromatogr A 2001;931:95-105.

24. de Morais P, Stoicheva T, Bastoa MCP, Vasconcelosa MTSD. Extraction and preconcentration techniques for chromatographic determination of chlorophenols in environmental and food samples. Talanta 2012;89:1-11.

25. Kragulj M, Trickovic J, Molnar J, Tubic A, Maletic S, Agbaba J, et al. Impact of different water matrices on analysis of chlorinated phenols. Water Res Manage 2013;3:27-33.

26. Khairy MA. Assessment of priority pheno- lic compounds in sediments from an extremely polluted coastal wetland (Lake Maryut, Egypt). Environ Monit Assess 2013;185:441-55.

27. Montero L, Conradi S, Weiss H, Poppa P. Determination of phenols in lake and ground water samples by stir bar sorptive extraction-thermal desorption-gas chromatography-mass spectrometry. J Chromatography A 2005;1071:163-9.

28. Pocurull E, Calull M, Marce RM, Borrull F. Determination of phenolic compounds at low $\mu$ g1-1 levels by various solid-phase extractions followed by liquid chromatography and diode-array detection. J Chromatogr A 1996;719:105-12.

29. Santana CM, Ferrera ZS, Santana JJR. Extraction and determination of phenolic derivatives in water samples by using polyoxyethylene surfactants and liquid chromatography with photodiode array detection. J AOAC Int 2004;87:166-71.

30. Alonso MC, Puig D, Silgoner I, Grasserbauer M, Barcelo D. Determination of priority phenolic compounds in soil samples by various extraction methods followed by liquid chromatographyatmospheric pressure chemical ionisation mass spectrometry. J Chromatography A 1998;823:231-9.

31. Vanbeneden N, Delvaux F, Delvaux FR. Determination of hydroxycinnamic acids and volatile phenols in wort and beer by isocratic high-performance liquid chromatography using electrochemical detection. J Chromatogr A 2006;1136:237-42.

32. Masque N, Galia M, Marce RM, Borrull F. Chemically modified polymeric resin used as sorbent in a solid-phase extraction process to determine phenolic compounds in water. J Chromatogr A 1997;771:55-61.

33. ICH (International Conference for Harmonization). Harmonised tripartite guideline, Q2(RI); validation of analytical procedures: text and methodology; Geneva: 1994.

34. ICH (International Conference for Harmonization). Validation of analytical procedures: methodology, adopted in Q2B; Geneva: 1996.

35. USFDA (United States Food and Drug Administration). Analytical procedures and methods validation: chemistry, manufacturing, controls and documentation; 2001. Available from: http://www. fda.gov/cvm

36. ISO/IEC 17025. General requirements for the competence of testing and calibration laboratories; 2005.

37. Huber L. Validation and qualification in analytical laboratories. New York: Informa Healthcare; 2007.

38. WDNR (Wisconsin Department of Natural Resources). LOD/LOQ Technical Advisory 
Committee Report, Analytical Guidance, PUBL-SW-130-93. Madison, WI: Laboratory Certification Program, Wisconsin Department of Natural Resources; 1994.

39. WDNR. Analytical detection limit guidance and laboratory guide for determining method detection limits, 1996; PUBL-05696.

40. USEPA (United States Environmental Protection Agency). Method 8000B: Determinative chromatographic separations (Rev 2); 1996.
41. Angelino S, Gennaro MC. An ion-interaction RP-HPLC method for the determination of the eleven EPA priority pollutant phenols. Anal Chimica Acta 1997;346:6171. 